\title{
Investigation of the Effects of Calcium Fructoborate on Testicular Structure in Rats within the Framework of Biochemical Parameters, Testosterone Hormone and DNA Damage in Cadmium Chloride Induced Toxicity
}

\author{
Saadet Belhann, ${ }^{1, *}$ Ahmet Ufuk Kömüroğlu², Uğur Özdek², Ali Sefa Mendil ${ }^{3}$, Ali Rıza Kul², \\ Muhammed Bahaeddin Dörtbudak, Arzu Gezer² \\ ${ }^{1}$ Department of Reproduction and Artificial Insemination, Faculty of Veterinary Medicine, Van Yuzuncu YIl University, Van, TURKEY. \\ ${ }^{2}$ Vocational School of Health Services, Van Yuzuncu YIl University, Van, TURKEY. \\ ${ }^{3}$ Department of Pathology, Faculty of Veterinary, Erciyes University, Kayseri, TURKEY. \\ ${ }^{4}$ Department of Pathology, Faculty of Veterinary Faculty, Atatürk University, Erzurum, TURKEY.
}

\begin{abstract}
Background: The present study aims to investigate the effects of calcium fructoborate on testicular DNA damage and testicular tissue biochemical markers and serum testosterone levels after cadmium chloride administration. Materials and Methods: 28 Wistar albino rats $(200-220 \mathrm{~g})$ in the study were divided into 4 groups with an equal number. These groups are; Control group (No chemicals applied), calcium fructoborate (100 mg) group, Cadmium chloride $(200 \mathrm{mg} / \mathrm{L})+$ calcium fructoborate $(100 \mathrm{mg})$, Cadmium chloride (200 $\mathrm{mg} / \mathrm{L})$ group. The study lasted 28 days and both chemicals were applied daily with oral gavage. Results: While 8-hydroxy-2-deoxyguanosine (8-OHdG) expression was moderate in the cadmium chloride + calcium fructoborate group, the expression in the cadmium chloride group was severe. In the cadmium chloride group, testicular tissue glutathione (GSH) and 8-OHdG levels, superoxide dismutase (SOD) and glutathione peroxidase (GPx) activities and serum testosterone levels were significantly decreased compared to other groups. It is determined that the reversal of the change in the parameters listed in the calcium fructoborate group. Conclusion: The reversal of the change in the parameters listed in the calcium fructoborate group indicates the positive strength of the present chemical. It is our suggestion to transfer calcium fructoborate into life practice by conducting further clinical studies and evaluating different parameters.
\end{abstract}

Key words: Cadmium chloride, Calcium fructoborate, Rat, 8-OHdG, Testosterone.

\section{INTRODUCTION}

Pollution in the atmosphere is a serious problem for both human health and other ecosystems. In this pollution, people, transportation vehicles and heavy metals play a big role. ${ }^{1}$ Cadmium, a heavy metal, has been reported to be abundant especially in industrial areas, ${ }^{2}$ causing injury in the liver, kidneys and testicles. ${ }^{3-9}$ Especially, in the toxicity it causes in the testicles, it has been reported that spermatogenesis is impaired and there are decreases in gonadotropic hormones and testosterone hormone. ${ }^{10-12}$ It has also been reported to cause apoptosis in the male reproductive cell. ${ }^{6}$ There are many studies in which oxidant / antioxidant balance is troubled after cadmium exposure. . $-6,8,9^{-1}$

Boron is an essential nutrient in animals as much as necessary for the normal growth and development of plants. ${ }^{13,14}$ It is emphasized that some fruits (Banana, apple, grape, peanut, hazelnut) and vegetables (carrot, potato, bean, broccoli, cabbage) have rich boron content. ${ }^{15}$ In boron deficiency, it
Submission Date: 06-08-2020; Revision Date: 02-12-2020; Accepted Date: 01-03-2021

DOI: 10.5530/ijper.55.2.92 Correspondence: Mrs. Saadet Belhan Associate Professor, Department of Reproduction and Artificial Insemination, Faculty of Veterinary Medicine, Van Yuzuncu YIl University, 65090, Van, TURKEY

Phone no: +90 4322251128 Email id: saadetkaratas@ hotmail.com

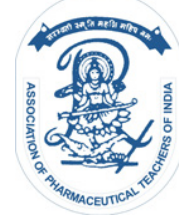

www.ijper.org 
has been reported that the number of sperm decreases in the frogs, sperm morphology is impaired and causes atrophy in the testicles and ovaries. ${ }^{16}$ Boron increases the level of testosterone in men, ${ }^{17}$ is important in the immune system, ${ }^{18,19}$ prevents osteoporosis ${ }^{20}$ and protects against some types of cancer. ${ }^{21,22}$ Boron contains many features such as anti-inflammatory, anticancer, disinfectant, antioxidant and antiapoptotic. ${ }^{23,24}$

Efforts are being made to find safe and convenient antioxidants from some plant extracts. ${ }^{25}$ Calcium fructoborate was obtained in 1998 as a US patent and was later developed. ${ }^{26}$ The calcium fructoborate form of boron, consisting of approximately 3\% boron, $5 \%$ calcium and $92 \%$ fructose, is found especially in grapes, plums, celery and broccoli. ${ }^{26,27}$ In the USA, calcium fructoborate is added to diets for bone health. ${ }^{28}$ Calcium fructoborate has been reported to have antioxidant, anti-inflammatory and antitumor effects. ${ }^{29-31}$

In this study, we tried to determine what effects calcium fructoborate will have on some of the biochemical and immunohistochemical problems that may occur after cadmium chloride application. In this context, from a biochemical point of view; testicular tissue glutathione $(\mathrm{GSH})$ superoxide dismutase (SOD) and glutathione peroxidase (GPx) were evaluated. Immunohistochemically also; 8-OHdG expression levels, an important marker for oxidative DNA damage, were determined.

\section{MATERIALS AND METHODS}

\section{Chemicals}

Cadmium chloride $\left(\mathrm{CdCl}_{2}\right)$ (655198 Sigma-Aldrich) was used as the cadmium source and FruiteX-B ${ }^{\circledR}$ Brand Calcium Fructoborate as the source of calcium fructoborate. The chemicals listed below were used immunohistochemically in our study: 8-OHdG (Abcam, Catalog No ab62623); HRP (Thermofischer, Catalog number: TP-125-HL). In addition to these, the following chemicals were used biochemically: GSH (Catalog no: SG-20391), SOD (Catalog no: SG-10188), GPx (Catalog no: SG-20976), 8-OHdG (catalog no: YLA0061RA).

\section{Animals and experimental design}

The study was performed on 28 (200-220 g) wistar albino male rats. In rats supplied from the Van Yuzuncu Y1l University Experimental Research Laboratory, ethical rules were observed in all applications. Prior to the study, the necessary permission was obtained from the Van Yuzuncu Yil University Ethics Committee (authorization number: 2020/41). Standard conditions existed in the care units of the rats. There was no restriction on feed intake. Care was taken for cleaning and ventilation.

Control group: No medication was applied.

Calcium fructoborate group: Calcium fructoborate $100 \mathrm{mg}$ was administered orally. In the study, both cadmium chloride and calcium fructoborate were applied daily for 28 days.

Cadmium chloride + calcium frultoborate group: Freshly prepared $200 \mathrm{mg} / \mathrm{L}$ cadmium chloride in drinking water was administered orally to 7 rats in this group. In addition, $100 \mathrm{mg}$ of calcium fructoborate was administered orally.

Cadmium chloride group: Freshly prepared $200 \mathrm{mg} /$ $\mathrm{L}$ cadmium chloride in drinking water was administered orally to 7 rats in this group. ${ }^{32}$

At the end of the 28 day working period, rats $75 \mathrm{mg}$ / kg i.p. They were anesthetized by applying ketamine. The testicles were taken for biochemical parameter evaluation and immunohistochemical evaluation. The testis taken for immunohistochemistry was left in a $10 \%$ neutral formalin solution.

\section{Immunohistochemical analysis}

Testicular tissues detected in neutral formalin $(10 \%)$ solution were subjected to alcohol-xylol treatment. Then, paraffin was taken into blocks. Sections of $5 \mu \mathrm{m}$ taken on polylysine slides were subjected to xylol and alcohol processes. It was washed with PBS and then endogenous peroxidase inactivation $(10 \mathrm{~m})$ was achieved in $3 \% \mathrm{H}_{2} \mathrm{O}_{2}$. Treated with antigen retrieval solution $(500$ watts for $2 \times 5$ $\mathrm{m})$. Then, washing was done with PBS. Then, 8-OHdG (Abcam, Catalog No ab 62623, 1/100 dilution rate) was incubated at room temperature $(20 \mathrm{~m})$ with the primary antibody. Secondary; Large Volume Detection System: Anti-Polyvalent, HRP (Thermofischer, Catalog number: TP-125-HL) was used as recommended by the manufacturer. DAB (3,3'-Diaminobenzidine) was used as a chromogen. After contrasting with Mayer's Hematoxylin, it was closed with entellan and examined under a light microscope. The examination was made as no $(-)$, mild $(+)$, moderate $(++)$ and severe $(+++)$ in the testicular tissues.

\section{Biochemical analysis}

It was studied by ELISA method using GSH (Catalog no: SG-20391), SOD (Catalog no: SG-10188), GPx (Catalog no: SG-20976) and 8-OHdG (catalog no: YLA0061RA) commercial kit.

\section{Statistical analysis}

The data obtained were analyzed with SPSS 20.00 (SPSS, Inc., Chicago, IL, USA) program. In terms of 
immunohistochemistry, the difference between the groups was determined by Kruskal Wallis, one of the nonparametric tests and the group that formed the difference was by the Mann Whitney $\mathrm{U}$ test $(p<0.05)$. Analysis of the biochemical data was carried out by one-way ANOVA followed by post hoc Tukey multiple comparison tests. Differences were considered significant at $p<0.05$

\section{RESULTS}

\section{Immunohistochemical findings}

In testicular tissues, a significant difference was detected between the groups in terms of 8 -OHdG immunpositivity (Table $1, p<0.05$ ). Immunpositivity of 8-OHdG was not significantly determined in testicular tissues of the control group and calcium fructoborate group (Figure 1). While 8-OHdG expression level was moderate in testicular tissues of cadmium chloride + calcium fructoborate group rats, 8-OHdG expression was found to be severe in testicular tissues of cadmium chloride group rats (Figure 1).

\section{Biochemical findings}

Control group testicular tissue GSH and 8-OHdG levels and SOD and GPx activities were significantly higher than the cadmium group. The cadmium group testicular tissue GSH and 8-OHdG levels and SOD and GPx activities were significantly lower than the cadmium + calcium fructoborate group. Serum testosterone level was significantly higher in the calcium fructoborate group than in the other groups. Serum testosterone level was significantly lower in the cadmium treated group than in the other groups. The serum testosterone level of the cadmium + calcium fructoborate group was significantly higher than the cadmium group. The findings obtained biochemically are presented in Table 2.

\section{DISCUSSION}

Cadmium is a industrial environmental pollutant, is taken by contaminated water, food and air and accumulates in various organs. ${ }^{33,34}$ Approximately $4500 \mathrm{mg} / \mathrm{kg}$ dose of boric acid creates toxicity in testicles in mice and rats. However, sugar compounds such as boron calcium fructoborate are practically non-toxic. ${ }^{26}$ It has even been reported that calcium fructoborate has an antioxidant effect by reducing the production of intracellular reactive oxygen species. ${ }^{29}$ Oxidative stress and inflammation have been reported to play a role in the pathogenesis of cadmium-induced testicular toxicity. ${ }^{35}$ Therefore, it was used in our calcium fructoborate study, which has antioxidant properties.

As a result of experimental studies, it has been reported that cadmium causes changes in reproductive hormone levels, disrupts spermatogenesis, causes DNA damage, induces apoptosis. ${ }^{6,10,11}$ In many studies, it has been reported that oxidative stress is induced in almost all organs of the body in acute or chronic cadmium exposure. In these studies in the literature list, we have learned that cadmium causes decreased levels of the indicator related to testicular oxidation in the testicular tissue. $^{4,5,7-9}$ In our current study, in cadmium chloride

\begin{tabular}{|c|c|c|c|c|}
\hline \multicolumn{2}{|c|}{ Table 1: Effect of cadmium chloride and calcium fructoborate on 8-OHdG expression levels. } \\
\hline Parameters & Control & Calcium fructoborate & $\begin{array}{c}\text { Cadmium chloride + } \\
\text { calcium fructoborate }\end{array}$ & Cadmium chloride \\
\hline $8-\mathrm{OHdG}$ & $0.16 \pm 0.40^{\mathrm{a}}$ & $0.33 \pm 0.51^{\mathrm{a}}$ & $1.83 \pm 0.40^{\mathrm{b}}$ & $2.83 \pm 0.40^{\mathrm{c}}$ \\
\hline $\mathrm{P}$ & $p<0.05$ & $p<0.05$ & $p<0.05$ & $p<0.05$ \\
\hline
\end{tabular}

Note: The subscript letters $(a, b, c)$ in the same column indicate significant differences between groups $(p<0.05)$.

8-OHdG: 8-hydroxy-2-deoxyguanosine

\begin{tabular}{|c|c|c|c|c|}
\hline Paramaters & Control & Calcium fructoborate & $\begin{array}{l}\text { Cadmium chloride }+ \text { calcium } \\
\text { frultoborate }\end{array}$ & Cadmium chloride \\
\hline GSH (ng/L) & $137.74 \pm 5.10^{\mathrm{a}}$ & $136.00 \pm 5.51^{a}$ & $137.100 \pm 4.71^{\mathrm{a}}$ & $124.00 \pm 2.68^{b}$ \\
\hline SOD (pg/ml) & $249.47 \pm 7.50^{\mathrm{a}}$ & $223.87 \pm 4.70^{b}$ & $206.10 \pm 8.53^{c}$ & $196.35 \pm 6.91^{d}$ \\
\hline GPx (IU/ml) & $35.10 \pm 2.63^{a}$ & $33.14 \pm 3.01^{b}$ & $31.30 \pm 2.87^{b}$ & $25.23 \pm 2.20^{c}$ \\
\hline 8-OHdG (ng/ml) & $0.60 \pm 0.04^{a}$ & $0.41 \pm 0.03^{b}$ & $0.42 \pm 0.04^{b}$ & $0.23 \pm 0.03^{c}$ \\
\hline Testosterone (nmol/l) & $2.30 \pm 0.31^{a}$ & $14.54 \pm 1.50^{c}$ & $7.48 \pm 0,51^{b}$ & $1.99 \pm 0,49^{a}$ \\
\hline
\end{tabular}

Note: The subscript letters $(a, b, c, d)$ in the same column indicate significant differences between groups $(p<0.05)$. 


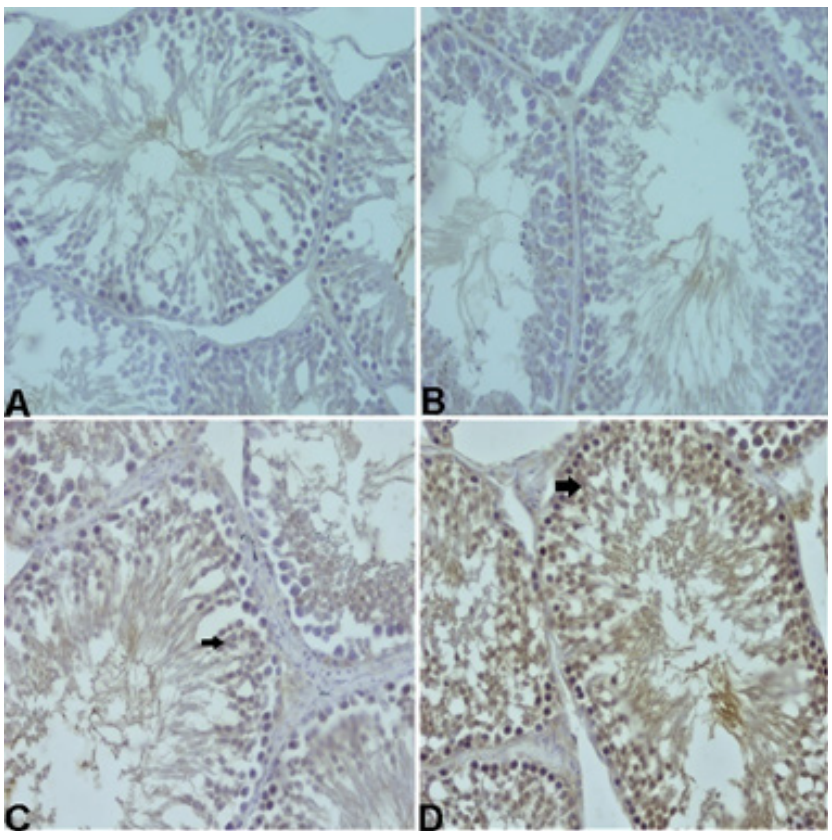

Figure 1: A (Control) and B (calcium fructoborate) group. Moderate 8-OHdG expression (arrow) in the $\mathbf{C}$ (cadmium chloride + calcium fructoborate) group testicle seminiferous tubules. Severe expression of 8-OHdG in the D (cadmium chloride) group testicle seminiferous tubules (arrow). Testicular-IHC.

group, SOD and GPx activity and GSH and testosterone levels were significantly lower than the control group. Our results support the previous studies. The interaction of cadmium with the metallic components of SOD may have been effective in the reduction of SOD activity. Because this can lead to inhibition of the enzyme. ${ }^{36,37}$ In the calcium fructoborate + cadmium chloride group, the calcium fructoborate significantly increased GSH and testosterone levels and SOD and GPx activities compared to the cadmium chloride group. In our current study, calcium fructoborate reduced the negative effects of cadmium chloride as much as possible by eliminating or minimizing free oxygen radicals and strengthening the antioxidant defense system in the testicle. We see more clearly the effect of calcium fructoborate, which we use to reduce or eliminate possible damage to the testicular tissue of cadmium compared to the group that only cadmium is administrated

In our study, we evaluated immunohistochemical 8-OHdG expression levels to detect DNA damage in testicular tissue, apart from biochemical parameters. We found that 8-OHdG expression levels were severe in the cadmium chloride group. Our findings with $8-\mathrm{OHdG}$ expression levels, which are a good marker for DNA damage, support previous studies. ${ }^{6,12}$ It was determined that the severity of 8-OHdG expression levels decreased in the cadmium chloride + calcium fructoborate group.
This may be due to the antioxidant effect of calcium fructoborate.

Based on our findings, we can say that calcium fructoborate, a boron compound, reduces the severity of oxidative stress and DNA damage in cadmium chloride induced testicular tissue. In order to test different activities of calcium fructoborate, we can suggest new studies to be done by changing the dosage and application times of calcium fructoborate and using different animals.

\section{CONCLUSION}

Based on our findings, we can say that calcium fructoborate, a boron compound, reduces the severity of oxidative stress and DNA damage in cadmium chloride induced testicular tissue. In order to test different activities of calcium fructoborate, we can suggest new studies to be done by changing the dosage and application times of calcium fructoborate and using different animals.

\section{ACKNOWLEDGEMENT}

The author thanks Van YuzuncuYil University for providing the necessary space to do her work.

\section{CONFLICT OF INTEREST}

There is no conflict of interest for the current study.

\section{ABBREVIATIONS}

DAB: 3,3'-Diaminobenzidine; GPx: Glutathione peroxidase; GSH: Glutathione; $\mathbf{H}_{2} \mathbf{O}_{2}$ : Hydrogen peroxide; i.p: Intra peritoneal; PBS: Phosphate buffer solution; 8-OHdG: 8-hydroxy-2-deoxyguanosine; SOD: Superoxide dismutase; $\mu \mathrm{m}$ : Micro meter.

\section{REFERENCES}

1. Blagnytė R, Paliulis D. Research into Heavy Metals Pollution of Atmosphere Applying Moss as Bioindicator: A Literature Review. Environ Res Eng Manag. 2010;54(4):26-33.

2. Järup L, Åkesson A. Current status of cadmium as an environmental health problem. Toxicol Appl Pharmacol. 2009;238(3):201-8.

3. Andjelkovic M, Djordjevic AB, Antonijevic E, Antonijevic B, Stanic M, KoturStevuljevic J, et al. Toxic Effect of Acute Cadmium and Lead Exposure in Rat Blood, Liver and Kidney. Int J Environ Res Public Health. 2019;16(2):274.

4. Faraji T, Momeni HR, Malmir M. Protective effects of silymarin on testis histopathology, oxidative stress indicators, antioxidant defence enzymes and serum testosterone in cadmium-treated mice. Andrologia. 2019;51(5):e13242.

5. Han C, Zhu Y, Yang Z, Fu S, Zhang W, Liu C. Protective effect of Polygonatum sibiricum against cadmium-induced testicular injury in mice through inhibiting oxidative stress and mitochondria-mediated apoptosis. J Ethnopharmacol. 2020;261:113060.

6. Li X, Yao Z, Yang D, Jiang X, Sun J, Tian L, et al. Cyanidin-3-O-glucoside restores spermatogenic dysfunction in cadmium-exposed pubertal mice 
via histone ubiquitination and mitigating oxidative damage. J Hazard Mater. 2020;387:121706.

7. Momeni HR, Eskandari N. Curcumin protects the testis against cadmiuminduced histopathological damages and oxidative stress in mice. Hum Exp Toxicol. 2020;39(5):653-61.

8. Olaniyi KS, Amusa OA, Oniyide AA, Ajadi IO, Akinnagbe NT, Babatunde SS. Protective role of glutamine against cadmium-induced testicular dysfunction in Wistar rats: Involvement of G6PD activity. Life Sci. 2020;242:117250.

9. Wang M, Wang X, Li Y, Chen N, Fan Y, Huang W, et al. Cross-talk between autophagy and apoptosis regulates testicular injury/recovery induced by cadmium via PI3K with mTOR-independent pathway. Cell Death Dis. 2020;11(1):46.

10. Nna VU, Ujah GA, Mohamed M, Etim KB, Igba BO, Augistine ER, et al. Cadmium chloride-induced testicular toxicity in male wistar rats: Prophylactic effect of quercetin and assessment of testicular recovery following cadmium chloride withdrawal. Biomed Pharmacother. 2017;94:109-123.

11. Badr GM, Elsawy H, Sedky A, Eid R, Ali A, Abdallah BM, et al. Protective effects of quercetin supplementation against short-term toxicity of cadmium-induced hematological impairment, hypothyroidism and testicular disturbances in albino rats. Environ Sci Pollut Res Int. 2019;26(8):8202-11.

12. Yıldırım S, Çelikezen FÇ, Belhan S, Oto G, Eser G, Şengül E, et al. Investigation of protective effects of lithium borate on spermatogenesis and testes histopathology against cadmium-induced acute toxicity in rats. Turk $\mathrm{J}$ Zool. 2020;44(3):291-301.

13. Warington $\mathrm{K}$. The effect of boric acid and borax on the broad bean and certain other plants. Ann Bot. 1923;37(148):629-72.

14. Nielsen FH. Evidence for the Nutritional Essentiality of boron. J Trace Elem Exp Med. 1996;9:215-29.

15. Hunt CD, Shuler TR, Mullen LM. Concentration of boron and other elements in human foods and personal-care products. J Am Diet Assoc. 1991;91(5):55868.

16. Fort DJ, Stover EL, Strong PL, Murray FJ. Effect of boron deprivation on reproductive parameters in Xenopus laevis. J Trace Elem Exp Med. 1999;12(3):187-204.

17. Naghii MR, Samman S. The effect of boron on plasma testosterone and plasma lipids in rats. Nutr Research. 1997;17(3):523-31.

18. Pizzorno L. Nothing boring about boron. Integr Med. 2015;14(4):35-48.

19. Dessordi R, Spirlandeli AL, Zamarioli A, Volpon JB, Navarro AM. Boron supplementation improves bone health of non-obese diabetic mice. J Trace Elem Med Biol. 2017;39:169-75.

20. Devirian TA, Volpe SL. The physiological effects of dietary boron. Crit Rev Food Sci Nutr. 2003;43(2):219-31.

21. Hunt CD. Dietary boron: Possible roles in human and animal physiology. Biomed Res Trace Elements. 2008;19(3):243-53.

22. Mahabir S, Spitz MR, Barrera SL, Dong YQ, Eastham C, Forman MR. Dietary boron and hormone replacement therapy as risk factors for lung cancer in women. Am J Epidemiol. 2008;167(9):1070-80.
23. Barranco WT, Kim DH, JrStella SL, Eckhert CD. Boric acid inhibits stored $\mathrm{Ca}^{2+}$ release in DU - 145 prostate cancer cells. Cell Biol Toxicol. 2009;25(4):30920.

24. Sogut I, Paltun SO, Tuncdemir M, Ersoz M, Hurdag C. The antioxidant and anti-apoptotic effect of boric acid on hepatoxicity in chronic alcohol-fed rats. Can J Physiol Pharmacol. 2018;96(4):404-11.

25. Lee SE, Ju EM, Kim JH. Free radical scavenging and antioxidant enzyme fortifying activities of extracts from Smilax china root. Exp Mol Med. 2001;33(4):263-8.

26. Scorei R. Boron, essential micronutrient for animal nutrition. Analele IBNA. 2006;22:75-85.

27. Hu H, Penn SG, Lebrilla CB, Brown PH. Isolation and characterization of soluble boron complexes in higher plants: The mechanism of phloem mobility of boron. Plant Physiol. 1997;113(2):649-55.

28. Hunter JM, Nemzer BV, Rangavajla N, Biță A, Rogoveanu OC, Neamtu J, et al. The fructoborates: Part of a family of naturally occurring sugar-borate complexes - biochemistry, physiology and impact on human health: A review. Biol Trace Elem Res. 2019;188(1):11-25.

29. Scorei R, Cimpoiasu VM, lordachescu D. In vitro evaluation of the anti-oxidant activity of fructoborate. Biol Trace Elem Res. 2005;107(2):127-34.

30. Scorei R, Ciubar R, Lancu C, Mitran V, Cimpean A, Iordachescu D. In vitro effect of calcium fructoborate on fMPL-stimulated human neutrophile granulocytes. Biol Trace Elem Res. 2007;118:27-37.

31. Scorei R, Ciubar R, Ciofrangeanu CM, Mitran V, Cimpean A, Iordachescu D. Comparative effects of boric acid and calcium fructoborate on breast cancer cells. Biol Trace Elem Res. 2008;122(3):197-205.

32. Oyinloye BE, Ajiboye BO, Ojo OA, Nwozo SO, Kappo AP. Cardioprotective and antioxidant influence of aqueous extracts from Sesamum indicum seeds on oxidative stress induced by cadmium in wistar rats. Pharmacogn mag. 2016;12 (Suppl 2): S170-4.

33. Mendiola J, Moreno JM, Roca M, Vergara-Juárez N, Martínez-García MJ, García-Sánchez A, et al. Relationships between heavy metal concentrations in three different body fluids and male reproductive parameters: A pilot study. Environ Health. 2011;10(1):6.

34. Guzikowski W, Szynkowska MI, Motak-Pochrzest H, PawlaczykA, Sypniewski S. Trace elements in seminal plasma of men from infertile couples. Arch Med Sci. 2015;11(3):591-8.

35. Fouad AA, Albuali WH, Jresat I. Simvastatin Treatment Ameliorates Injury of Rat Testes Induced by Cadmium Toxicity. Biol Trace Elem Res. 2013;153(13):269-78.

36. Acharya UR, Mishra M, Patro J, Panda MK. Effect of vitamins C and $\mathrm{E}$ on spermatogenesis in mice exposed to cadmium. Reprod Toxicol. 2008;25(1):84-8.

37. Farjad E, Momeni HR. Silymarin ameliorates oxidative stress and enhances antioxidant defense system capacity in cadmiumtreated mice. Cell J. 2018;20(3):422-6.

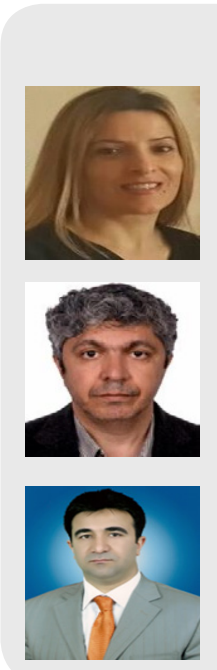

\section{About Authors}

Saadet Belhan, She was born in Turkey. She completed her university education at Firat University, Faculty of Veterinary Medicine. She completed her Doctorate in Van Yuzuncu Yil University, Faculty of Veterinary Medicine, Department of Reproduction and Artificial Insemination. She worked at the Ministry of Agriculture and Forestry for a while. Saadet Belhan is an expert in Andrology and artificial insemination. She is working as an Associate Professor at the same university.

Ahmet Ufuk Kömüroğlu, He was born in Turkey. He completed his undergraduate education at the Biochemistry Department of Van Yuzuncu Yil University. Later he completed his doctorate education in the same field. He has experience in biochemistry fields such as Elisa and spectrophotometric methods. He continues to work as a Assistant Professor at Van Yuzuncu Yil University Health Services Vocational School.

Uğur Özdek, He was born in Turkey. He completed his university education at Firat University, Faculty of Science, Department of Chemistry. He completed his master's and doctoral studies at Van Yuzuncu Yil University. He has experience in Biochemistry fields such as ELISA and spectrophotometric methods. He works as an Assistant Professor at the same university. 




Ali Sefa Mendil, He was born in Turkey. He completed her undergraduate education at Atatürk University Faculty of Veterinary Medicine. He started her Doctorate education in Erciyes University Veterinary Faculty Pathology Department in 2020. He has experience in Western blot, immunohistochemistry and immunofluorescent staining.

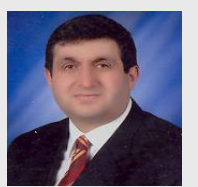

Ali Rıza Kul, He was born in Turkey. He completed his undergraduate education at Cukurova University. He completed my Master's and Doctoral studies at Van Yuzuncu Yil University. He works in the fields of environment and health. He is an expert in instrumental devices. He is still working as an Assistant Professor at the same university.

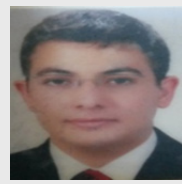

Muhammed Bahaeddin Dörtbudak, He was born in Turkey. He completed his undergraduate education at Harran University Faculty of Veterinary Medicine. He completed his doctorate education at Atatürk University Faculty of Veterinary Medicine, Department of Pathology. He works at Bingöl University, Faculty of Veterinary Medicine, Department of Pathology. He has experience in Western blot, immunohistochemistry and immunofluorescent staining.

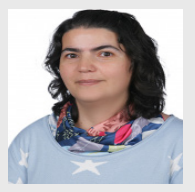

Arzu Gezer, She was born in Turkey. She completed her undergraduate education at the Department of Histology and Embryology at Kafkas University. She later started her doctorate education in the same field. Her doctorate education is still continuing. She works as an Instructor at Atatürk University Health Services Vocational School.

PICTORIAL ABSTRACT
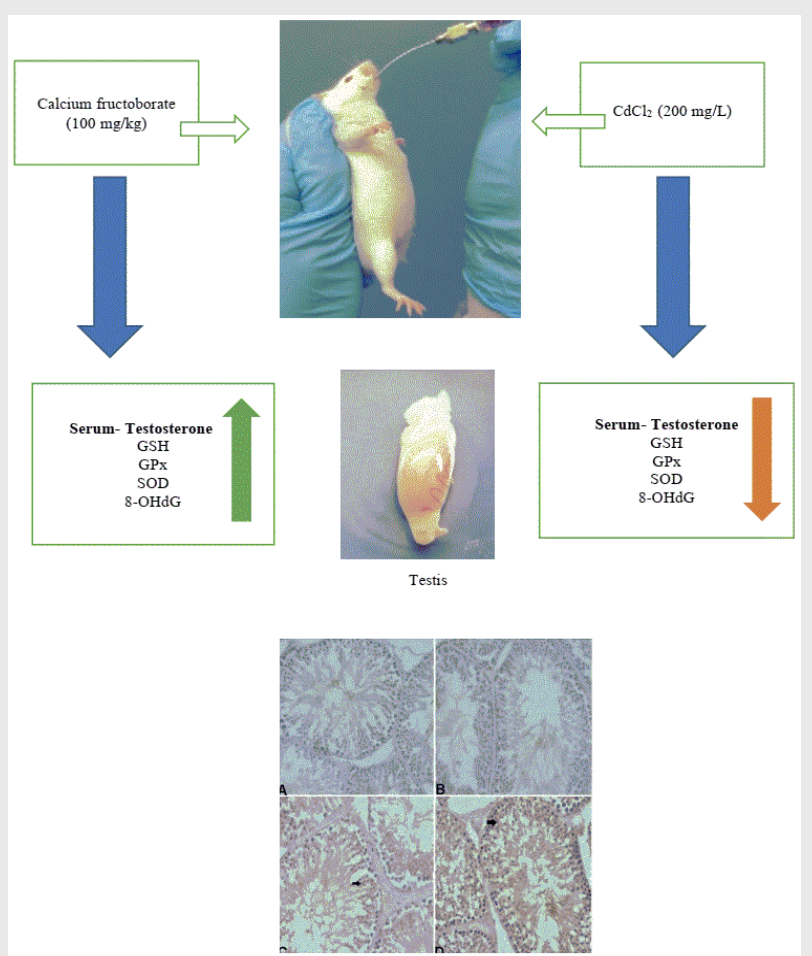

Testicular Tissue

\section{SUMMARY}

In this study, it was determined that calcium fructoborate had positive effects on DNA damage and biochemical markers and serum testosterone levels in testicular tissue after application of cadmium chloride. The protective effect of calcium fructoborate was confirmed as a result of the finding listed below after daily oral gavage application in study that continued for 28 days.

1- Expression of 8-hydroxy-2-deoxyguanosine (8-OHdG) was moderate in cadmium chloride + calcium fructoborate group, while expression was severe in cadmium chloride group.

2- In the cadmium chloride group, testicular tissue glutathione (GSH) and 8-OHdG levels, superoxide dismutase (SOD) and glutathione peroxidase (GPx) activities and serum testosterone levels were significantly lower than other gropus.

The reversal of the change in the parameters listed in the calcium fructoborate group had indicated the postive strength of the present chemical.

Cite this article: Belhan S, Kömüroğlu AU, Özdek U, Mendil AS, Kul AR, Dortbudak MB, et al. Investigation of the Effects of Calcium Fructoborate on Testicular Structure in Rats within the Framework of Biochemical Parameters, Testosterone Hormone and DNA Damage in Cadmium Chloride Induced Toxicity. Indian J of Pharmaceutical Education and Research. 2021;55(2):544-9. 